\title{
Effect of ease of doing business dimensions on foreign direct investment in Nigeria
}

\author{
Vincent Okwudili Iweama ${ }^{1}$, Edwin Chukwuemeka Idoko ${ }^{2, *}$, Yusuf Musa Muhammad ${ }^{3}$ \\ ${ }^{1}$ Department of Management Studies, Nigeria Police Academy, Nigeria \\ ${ }^{2}$ Department of Marketing, University of Nigeria, Enugu Campus, Enugu, Nigeria \\ *Corresponding Author \\ Email: edwin.idoko@unn.edu.ng (Edwin Chukwuemeka Idoko)
}

\begin{abstract}
In Sub-Saharan Africa countries, there is growing interest regarding attraction of foreign direct investments in order to sustainably grow economy. Despite the fact that Nigeria is the economic hotspot in Sub-Saharan Africa, recent declining foreign direct investment statistics is increasingly becoming a serious concern to government. Regrettably, constraining factors have been under-researched leading to little understanding among policy-makers. This paper examines dimensions of ease of doing business on foreign direct investment in Nigerian economy. Survey research was adopted as the design of the study. The population of the study comprises registered small and medium enterprises in Southeastern Nigeria. A sample of 300 respondents where statistically determined. The study used primary data which were generated through the administration of structured questionnaire on the representative sample of the population. Descriptive statistics such as percentages was used to describe the demographic characteristics of respondents while hypotheses of the study were tested using
\end{abstract}


regression analysis. The study finds that power supply, security, transportation as dimension of ease of doing business has significant impact on foreign direct investment in Nigeria. The paper concludes that Nigeria, a leading economic hotspot in Sub-Saharan Africa needs to reexamine prevailing business constraints and redefine its business model in order to attract more foreign investors into the economy. The policy and managerial implications of the findings are highlighted.

Keywords: Foreign Direct Investment, Ease of Doing Business, Nigeria

\section{Introduction}

Low income countries in their developmental process are becoming increasingly conscious of the fact that Foreign Direct Investment (FDI) is a major stimulus to economic growth given the inadequacy of financial resources, technology and skills. Admittedly, the last few decades, have been characterized by intensive research on the growth-enhancing effects of FDI to developing economies (Mahuni \& Bonga, 2017; World Bank, 2016). Doing-business measures aspect of business regulations for domestic firms; it presents quantitative indicators on the regulations that apply to firms at different stages of their life cycle. Doing business index is an annual ranking that objectively assesses prevailing business climate conditions across 190 countries. Doing business is based on ten ease-of-doing-business indicators such as starting business, registering property, getting credit, paying taxes, enforcing contracts, getting electricity, trading across borders, construction permits, protecting minority shareholders and resolving insolvency (World Bank, 2020; Okri, 2020; Singh, 2015).

It should be noted that Nigeria accounts for approximately one-fourth of sub-Saharan Africa's population by being the seventh most populous country in the world. However, as of April 2014, the country is recognized as the continent's largest economy. Recently, Nigeria is however ranked as the $13^{\text {th }}$ in the world in terms of its oil production. Hence, it is believed to be one of African largest oil producers and holds the second highest oil reserves on African continent after Libya (Olagunju \& Ikeolumba, 2019). In spite of its large reserves of human and natural resources, a large domestic market, and strong economic fundamentals, Nigeria is not yet positioned to join the group of large emerging markets and be the continents economic and political strong hold (Djankov, 2002). The business climate in Nigeria is unfriendly; a 
burdensome investment climate creates unnecessary business hurdles and affects the foreign direct investment (World Bank Group, 2018)

As part of the Nigeria government efforts to improve its performance in the World Bank's ease of doing business index as well as easing the process of doing business in Nigeria particularly for foreign investors, the Nigeria government set up a committee known as Presidential Enabling Business Environment Council that has been saddled with the responsibility of devising means of simplifying the process of establishing and sustaining businesses in Nigeria. The World Bank's 2020 Doing Business Index (DBI) ranked Nigeria 131 st out of 190 countries, up 15 places from 146th position last year, up from 170th since 2014 is an indication of progress in Nigeria. This was achieved as a result of the establishment of the Presidential Enabling Business Environment Council (PEBEC) in Nigeria. PEBEC has the aim of minimizing the constraints that come with running business in the country, works towards the fulfillment of the projections of the Economic Recovery and Growth Plan (ERGP2017 - 2020), which strives to deliver sustainable economic growth in Nigeria by building a competitive economy. Although, the committee has been able to proffer a few changes such as single form for incorporation, decentralized registration, and automation/online search, a lot still needs to be done (Durojaye, 2018)

Nigeria is blessed with abundance of natural and human resources. It is estimated that the country has about 61 mineral resources, each of which has the capacity to sustain the economy (CBN, 2013). Unfortunately, these resources are largely lying latent and the economy is mono-culturally dependent on petroleum for its survival. Over 90 per cent of Nigeria's foreign receipts are accounted for by oil and because of volatility of oil prices, the economy suffers when there is a glut in the international oil market (Onu, 2012). Besides, because there is a nexus between the oil sector and the rest of the local economy, unemployment is high, poverty is prevalence and security is a current challenge (Uwubanmwen \& Ogiemudia, 2016). A key reason for this situation is inadequate capital and technical knowhow necessary to tap from the abundant unemployed resources (Jerome \& Ogunkola, 2004). The need for technological advancement is imperative in Nigeria. The country is in dire need to expand its output, improve its resource use, enhance social welfare and limit its overdependence on oil exports (Nwankwo, Ademola, \& Kehinde, 2013). This has informed the search for strategies that will generate economic growth. One such strategy is the foreign investment and ease of doing business. Foreign investment and ease of doing business are believed to be key source of productivity expansion because they have capacity 
for technology transfer. Foreign investment and ease of doing business can also increase access to foreign markets and in concert with local resources can increase competitiveness of products because of cheap labour in host countries (Solomon \& Eka, 2013; Igbinadolor, 2019).

It is however regrettable that over 50 years after independence, Nigeria is still finding it difficult to attract both domestic and foreign direct investment due to the complexity of doing business. According to UNCTAD (2019) World Investment Report, FDI flows to Nigeria was USD 1.9 Billion in 2018, and showed a decrease compared to the previous year, USD 3.5 billion in 2017 (UNCTAD, 2019). This situation needs to be urgently addressed by government. In view of the current state of Nigeria's economy, which is faced with dwindling oil revenue, devaluation of the Naira and a slowing gross domestic product (GDP) growth rate, it has become imperative to redefine Nigeria's investment climate (Redefining The Ease of Doing Business, 2016). Since 2008, the ease of doing in Nigeria has been receiving much effort to make it easier for entrepreneurs to start and operate a business across Nigeria and attract foreign direct investment but a lot still needs to be done (Daily Post, 2017).

Ease of doing business is an index created jointly by Simeon Djankov and Gerhard Pohl at the Central and Eastern Europe sector of the World Bank Group. The academic research for the report was jointly done with Professors Oliver Hart and Andrel Shleifer. It looks at the ten indicators and assigns values to them to show the complexity or simplicity of regulations and how they enable or disenable business performance (World Bank Group, 2011). However, these indicators are more suitable to developed economies' business environments. Yusuf (2019) called for indicators that reflect the Nigerian condition in the globe ease of doing business rankings. Some of the indicators in the ease of doing business composition do not properly capture the critical variables in Nigeria environment. Issues of security, transportation and Nigeria regulatory environment are not captured while power is not adequately captured. There is need to address these other variables that are not on the list of ease of doing business parameters. In many of the developed countries, indicators such as transport, power and security are taken for granted, whereas in Nigeria, these are big issues. It is against this back drop that this paper succinctly seeks to evaluate the paradoxes that have beclouded the ease of doing business in low income countries especially Nigeria.

\section{Empirical Review and Hypotheses Development}

\subsection{Global Ease of Doing Business Indicators}


The global application of ease of doing business commenced in 2011, with 10 sub-indices for ranking nations as follows: starting business, registering property, getting credit, paying taxes, enforcing contracts, getting electricity, trading across borders, construction permits, protecting minority shareholders and resolving insolvency (World Bank, 2020). With the growing number of small-and-medium enterprises, ease of doing business plays a crucial role in the region's economic growth. While ease of doing business has implications for foreign direct investments, local businesses too are impacted by the processes that can help promote a business-friendly environment or hold local businesses sustain their entrepreneurial ambitions (Friedrich Naumann Foundation, 2017)

Domestics and foreign tax policies affect the incentives to engage in foreign direct investment (Fahmi, 2012). Tax regimes in Afghanistan, Bangladesh, India, Iran, Pakistan and Sri Lanka have shown evidence of high FDI inflow (Shahadan, Sarmidi, \& Faizi, 2014). According to Moosa (2002), one of the approaches in which tax policies affect multinational company's decision making is the impact tax has on income earned from abroad operations on net return of foreign investment. The fact that compared to countries with lower income tax rate, countries with high income tax rate would attract companies to invest abroad; hence, taxes play a role in the preliminary decision to invest abroad (Fahmi, 2012). Therefore, tax rate differences will significantly impact on investment decisions and ease of doing business. In multiple researches, this statement was found to be true for most of the countries (Singh, 2015; MogesEbero \& Begum, 2016; Akame et al, 2016).

Hassan and Basit (2018), used panel data to investigate the impact of ease of doing business on inward FDI over the period from 2011 to 2015 across the globe (177 countries) respectively, they used 5 indicators (areas) of doing business such as: starting a business, getting credit, registering property, paying taxes and enforcing contracts. They emphasize that enforcing contracts was found to have a positive impact on inward FDI, while getting and registering property were found to have a negative significant impact on inward FDI among others. Mahuni and Bonga (2017), analyzed the impact of ease of doing business indicators on FDI inflows in Zimbabwe employing a Time Series Analysis for the period from 2009 - 2016 using the OLS regression model. They pointed that paying taxes, enforcing contracts and getting electricity had negative significant impact on FDI inflows. The study suggest that there is a greater need to improve efficiency in the enforcement of contracts, fair distribution of electricity and energy, improving taxes procedure and correctly dealing with construction permits. Also, Shahadan et al (2014), by using panel data for six Asian countries for the 
period 2004 - 2013, investigated 9 indicators of doing business in attracting FDI net inflows through pooled OLS, fixed effect and random effect models estimations. Olival (2012) used the panel data to investigate 9 global business indicators in 144 developing countries and 33 developed countries for the period 2004 - 2009. It tried to find a link between 9 indicators of ease of doing business and FDI. The major implication is that in general, a better-rated business environment is more likely to attract greater amount of FDI, especially in the case of developing countries. Further institutional areas that are more likely to influence inward FDI are: starting a business, registering a property and trading across borders. On the basis of this narration, we hypothesize that:

H1: Global ease of doing business indicators has no significant impact on foreign direct investment.

\subsection{Security}

Godly and Wilfred (2012) posit that national security and advancement are positively related to security and economic progress while insecurity is crippling to the monetary advancement of many less developed economies. Nwanegbo and Odigbo (2013) report that terrorism and insecurity thwart the development improvement, ease of doing business and foreign direct investment. Insecurity obstructs business exercises and debilitates local and international financial patronages (Ewetan \& Urhie, 2014)

Gylych, Kemal and Sotonye (2018) carried out empirical research on the effect of insecurity on investment in Nigeria from 2007 to 2017, using three variables as input: Nigeria Terrorism Index, Foreign Direct Investment (Inflow), and Oil Prices. The study employed the use of correlation and regression techniques to analyse the collected data; using Nigeria Terrorism Index as a proxy for insecurity and foreign direct investment (inflows) as a proxy for investment. It recommends that government must be pre-emptive in dealing with security issues and threats, in view of managing security challenges. Udeh and Ihezie (2013) report that insecurity challenges impact on national economic improvement and FDI inflows and their commitments to monetary improvement and ease of doing business in Nigeria. Achumba, Ighomereho and Akpor-Rebaro (2013) report that the effects of insecurity in Nigeria are colossal and complex and will continue to negatively affect the ease of doing business in Nigeria if the circumstance stays unabated. Thus we pose the following hypothesis:

H2: Security has no significant impact on foreign direct investment in Nigeria

\subsection{Power Supply}


The business and industrial sector in Nigeria is experiencing sluggish growth. The survey by Manufacturers Association of Nigeria painted a gloomy picture of the Nigerian industrial sector crisis. For instance, the survey showed that only 10 percent of manufacturing concerns in Nigeria operate at 48.8 percent of installed capacity. The survey also notes that about 60 percent of the companies operating were barely able to cover their average variable costs, while 30 percent had completely closed down. According to that report, most of the industrial areas around the country suffered an average of 14.5 hours of power outage per day against 9.5 hours of supply, and the cost of generating power supply by firms for production constitutes about 36 percent of total cost of production (Okafor, 2008). The supply of electricity in Nigeria is facing crisis as exemplified by such indicators as electricity blackouts and persistence on self-generating electricity. Ekpo (2009) argues that Nigeria is operating a generator-dependent economy which potentially affects production cost including ease-ofdoing business. The country's electricity market is dominated on supply side by a state owned monopoly - Nigeria Electricity Distribution Company (NEDC) - private and current owner of defunct Power Holding Company of Nigeria (PHCN); it has been adjudged incapable of providing minimum acceptable international standard of electricity. Driving economic development through industrialization and FDI requires dramatic improvement electricity supply (Ologundudu, 2015). Oke (2006) attributed non-competitiveness of Nigeria's export goods to poor infrastructure especially electricity supply which drives the running cost of firms. Power supply is the major problem facing even established companies and organizations in Nigeria. However, government has not been able to discover an enduring remedy to the power supply situation in Nigeria which affects the big organizations including the multinationals down to the one man businesses who depends on power to run their businesses (Olagunju \& Ikeolumba, 2019). On the basis of this discussion, we hypothesize that:

H3: Power supply has no significant impact on foreign direct investment in Nigeria

\subsection{Transport System}

Agbigbe (2016) reported that the United Nations Development Programme (UNDP) described Nigeria's road networks as one of the poorest and deadliest transportation infrastructural systems in the world. Corruption in awarding road contracts, lack of contract monitoring affects the quality of roads and ease of doing business in Nigeria. Gulyani (2001) posited that poor transportation system adversely affect industrial competiveness by raising the unit cost of freight and affects the ease of doing business. The physical infrastructure such as ports, 
airports, roads and rail networks are capacity constrained and poorly maintained. The freight services provided by private and public sector operations tend to be limited in range, poor in quality, and often technologically obsolete in many developing countries. Bad roads had effects on transportation system as it brought about frequent break down of vehicles and increased maintenance cost, thus affecting ease of doing business. Poor road condition and transport system hinder movement of goods and people in the urban areas. Lack of adequate infrastructure could be a disincentive to both local and foreign investors and effects ease of doing business. World Economy Forum (2017) reported that Nigeria does not have a good transportation network, most roads are not in good shape and the railways and waterways have not been fully established. Most organizations and companies locate their businesses near their source of materials or market to help save cost and time. But in cases where this is not possible, the problem of transportation will come up. The Nigeria business environment lacks basic amenities and infrastructure that aids and helps business development and survival (Djankov, 2002). This in the long run leads to more money being spent and difficulty in doing business. Consequently, we hypothesize that:

H4: Transport system has no significant impact on foreign direct investment in Nigeria

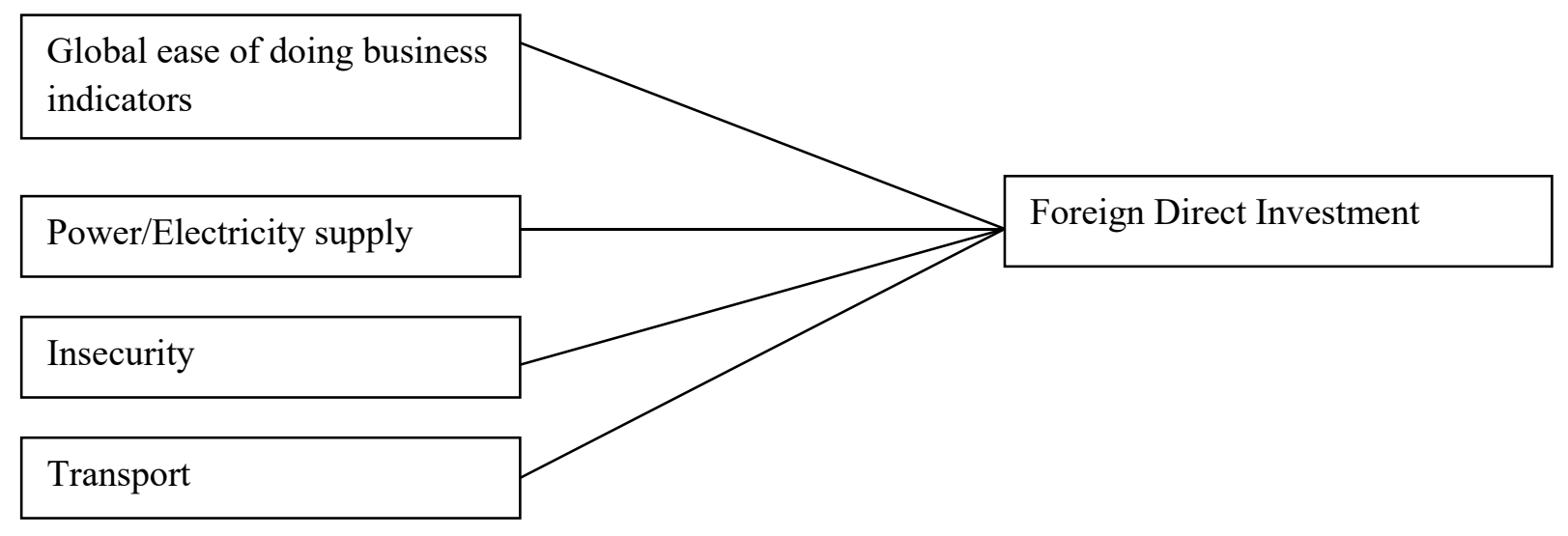

Figure 1: Proposed theoretical model for the study

\section{Methodology}


The study adopted descriptive survey research design; the population of the study comprises registered small and medium scale enterprises in Southeastern Nigeria. A sample of three hundred (300) respondents was determined statistically for the purpose of the study. Copies of structured questionnaire were administered to respondents on drop-and-collect basis by the researchers. Instructions were provided on the survey instrument on how to complete the questionnaire. Upon completion, the questionnaires were retrieved from the respondents on the spot. The data collected were analyzed using Statistical Package of Social Sciences Version 25. Descriptive statistics of frequencies and percentages were used to describe the demographic characteristics of the respondents; mean and standard deviation were employed to resolve the research questions, while the hypotheses were tested using regression statistics

\section{Data Analysis and results}

\subsection{Socio - Demographics}

Table 1: Descriptive Statistics Researcher's Conceptualization, 2020

\begin{tabular}{|lccc|}
\hline Descriptive Statistics & & & \\
\hline Items & Mean & $\begin{array}{c}\text { Std } \\
\text { Deviation }\end{array}$ & $\begin{array}{c}\text { Correlation } \\
\text { Index }\end{array}$ \\
\hline Global Business Indicators (IV) & 12.056 & 1.4423 & $0.984^{* *}$ \\
Foreign Direct Investment (DV) & 84.803 & 10.082 & \\
Power Supply (IV) & 17.143 & 2.435 & $-0.871^{* *}$ \\
Foreign Direct Investment (DV) & 84.803 & 10.082 & $-0.683^{* *}$ \\
Security (IV) & 10.303 & 2.014 & \\
Foreign Direct Investment (DV) & 84.803 & 10.082 & $-0.960^{* *}$ \\
Transport System (IV) & 9.6500 & 1.1821 & \\
Foreign Direct Investment (DV) & 84.803 & 10.82 & \\
\hline
\end{tabular}

Source: Researchers' Conceptualization, 2020

The survey recorded a response rate of $300(100 \%)$, because copies of questionnaire were administered to respondents on a face-to-face basis by the researchers and respondents were instructed on how to fill-in the questionnaire. Based on the samples, the ratio of male to female is $61-39 \%$. The age distribution of respondents within the age brackets of $18-25$ constitute $4 \%$, while those of $26-33$ age bracket constitute $7 \%$ of sampled respondents; $34-41$ age bracket constitute 35\%; however, those within $42-49$ age bracket constitute $42 \%$ of respondents; and respondents of 50 years and above is $12 \%$. The age distribution reveals the dominance of middle and advanced generation as $89 \%$ of the respondents. With regard to 
marital status; $61 \%$ of the respondents are married; $33 \%$ are single; $2 \%$ are separated; $2 \%$ are widows; $1 \%$ is widower; and $1 \%$ is divorced. Furthermore, the descriptive statistics is somewhat suggestive that more of the respondents are married individuals.

Table 2: Regression Analysis

\begin{tabular}{|c|c|c|c|c|c|}
\hline \multicolumn{6}{|c|}{ Assessment of the measurement Model: Regression Analysis } \\
\hline Model & $\begin{array}{l}\text { Sum of } \\
\text { Squares }\end{array}$ & Df & Mean Square & F & Sig \\
\hline \multicolumn{6}{|c|}{ Global Business Indicators } \\
\hline Regression & 29440.032 & 1 & 29440.032 & 183.016 & .012 \\
\hline Residual & 955.365 & 298 & 3.206 & & \\
\hline Total & 30395.397 & 299 & & & \\
\hline \multicolumn{6}{|c|}{ Poor Power Supply } \\
\hline Regression & 23035.363 & 1 & 23035.363 & 932.678 & $.000^{\mathrm{t}}$ \\
\hline Residual & 7360.034 & 298 & 24.698 & & \\
\hline Total & 30395.397 & 299 & & & \\
\hline \multicolumn{6}{|l|}{ Insecurity } \\
\hline Regression & 14179.243 & 1 & 14179.243 & 260.568 & $.000^{\mathrm{t}}$ \\
\hline Residual & 16216.154 & 298 & 54.417 & & \\
\hline Total & 30395.397 & 299 & & & \\
\hline \multicolumn{6}{|c|}{ Poor Transport System } \\
\hline Regression & 28019.905 & 1 & 28019.905 & 3515.033 & .002 \\
\hline Residual & 2375.492 & 298 & 7.971 & & \\
\hline Total & 30395.397 & 299 & & & \\
\hline
\end{tabular}

Table 3: Model Summary

\begin{tabular}{|c|c|c|c|c|c|c|c|c|c|}
\hline \multirow{3}{*}{$\begin{array}{l}\text { Model } \\
\text { of }\end{array}$} & \multirow{3}{*}{$\mathrm{R}$} & \multirow[t]{2}{*}{$\mathrm{R}$ square } & \multirow[t]{2}{*}{ Adjusted } & \multirow[t]{2}{*}{ Std Error } & \multicolumn{5}{|c|}{ Change Statistics } \\
\hline & & & & & $\mathrm{R}$ & $\mathrm{F}$ & $\mathrm{dF}$ & $\mathrm{df}$ & $\mathrm{F}$ \\
\hline & & & R Square & the & Sqr & Chg & 1 & 2 & Chg \\
\hline Estimat & & & & & Chg & & & & \\
\hline GBI & $.984^{2}$ & .968 & .968 & 1.79051 & .969 & 9183.016 & 1 & 298 & .000 \\
\hline PS & $.871^{2}$ & .758 & .757 & 4.96972 & .758 & 932.678 & 1 & 298 & .000 \\
\hline SEC. & $.683^{2}$ & .466 & .465 & 7.37676 & .466 & 260.568 & 1 & 298 & .000 \\
\hline TS & $.960^{2}$ & 922 & .922 & 2.82338 & .922 & 3515.033 & 1 & 298 & .000 \\
\hline
\end{tabular}


Table 4: Regression Coefficients

\begin{tabular}{|c|c|c|c|c|c|c|}
\hline \multirow{2}{*}{\multicolumn{2}{|c|}{ Model }} & \multicolumn{2}{|c|}{$\begin{array}{l}\text { Un-standardized } \\
\text { Coefficients }\end{array}$} & \multirow{2}{*}{$\begin{array}{c}\text { Standardized } \\
\text { Coefficients }\end{array}$} & \multirow{2}{*}{$\mathrm{t}$} & \multirow{2}{*}{ Sig } \\
\hline & & $\mathrm{B}$ & $\begin{array}{c}\text { Std } \\
\text { Error }\end{array}$ & & & \\
\hline (Constant) & & 1.859 & .872 & & & \\
\hline 2.132 & .034 & & & & & \\
\hline Global Bus & iness & 6.880 & .072 & .984 & & \\
\hline 95.828 & .000 & & & & & \\
\hline Indicator & & & & & & \\
\hline (Constant) & & 23.008 & 2.044 & & & \\
\hline 2.132 & .034 & & & & & \\
\hline Power & & 3.605 & .118 & .871 & & \\
\hline 30.540 & .000 & & & & & \\
\hline Supply & & & & & & \\
\hline (Constant) & & 49.582 & 2.223 & & & \\
\hline 22.303 & .000 & & & & & \\
\hline security & & 3.418 & .212 & .683 & & \\
\hline 16.142 & .000 & & & & & \\
\hline (Constant) & & 5.819 & 1.342 & & & \\
\hline 4.335 & .000 & & & & & \\
\hline Transport & & 8.185 & .138 & .960 & & \\
\hline 59.288 & .000 & & & & & \\
\hline System & & & & & & \\
\hline
\end{tabular}

\section{Discussion of Findings}

Global business indicators have positive and direct impacts on foreign direct investment. The higher the global business indicators indicate the ease of doing business; also the likelihood of foreign direct investors. As shown in Table 3, the positive Correlation index is 0.984 . Power supply has negative and inverse impact on ease of doing business. The higher the poor power supply the lower the ease of doing business and foreign direct investment in Nigeria; the negative Correlation index of -0.871 is evident in Table 1 . Security has negative and inverse impact on foreign direct investment in Nigeria. Higher the insecurity is associated with lower 
foreign direct investment in Nigeria. The negative Correlation index of -0.683 is shown in Table 1. Also, transport system has negative and inverse impact on ease of doing business by foreign direct investment in Nigeria. The higher the poor transport system the lower the attraction of foreign direct investment. This is shown in the negative Correlation index of 0.960 in Table 1.

Regression statistics in Table 2 show that Global business indicators have significant impacts on foreign direct investment; reasons being that in the Regression ANOVA statistics the calculated $\mathrm{p}$ value of 0.012 is lower than the 0.05 alpha level of significance and the computed $183.016 \mathrm{~F}$ value is greater than the $3.00 \mathrm{~F}$ critical value, while the mean square is 29440.032. The findings in table 2 showed that power supply has significant impact on foreign direct investment; reason is that in the regression ANOVA statistics the calculated pvalue of 0.000 is $<0.05$ alpha level of significance and the computed $932.678 \mathrm{~F}$ value is greater than the $3.00 \mathrm{~F}$ critical value, while the mean square is 23035.363. Also, the regression analysis in table 2 demonstrates that security has significant impact on direct foreign investment. This is because in the Regression ANOVA statistics the calculated pvalue of 0.000 is $<0.05$ alpha level of significance and the computed $260.568 \mathrm{~F}$ value is greater than the $3.00 \mathrm{~F}$ critical value, while the mean square is 14179.243. Furthermore, regression statistics in table 2 showed that transport system has significant impact on foreign direct investment. The reasons is that, in the regression ANOVA statistics the calculated $p$ value of 0.002 is lower than the 0.05 alpha level of significance and the computed $3515.033 \mathrm{~F}$ value is greater than the $3.00 \mathrm{~F}$ critical value, while mean square is 28019.905 .

The Model summary in table 3 showed that the values if $R, R$ square and Adjusted R square values of $0.984,0.969$ and 0.968 is each higher than the standard Regression value of 0.4000 ; a computed $9183.016 \mathrm{~F}$ change and 1.79051 standard error estimate, this shows that Global business indicators have significant impact foreign direct investment and null hypothesis hereby rejected. Also, Table 3 shows that the values if $\mathrm{R}, \mathrm{R}$ square and Adjusted $\mathrm{R}$ square values of $0.871,0.758$ and 0.757 is each higher than the standard Regression value of 0.4000 , a computed $932.678 \mathrm{~F}$ change and 4.96972 standard error estimate, shows null hypothesis which says that power supply has no significant impact on foreign direct investment, is hereby rejected. Furthermore, Table 3 shows that the values of R, R square and Adjusted R square values of $0.683,0.466$ and 0.465 is each higher than the standard regression value of 0.4000 ; a computed $F$ change of 260.568 and 7.37676 standard error, therefore, the null hypothesis which states that security has no significant impact on FDI is hereby rejected. 
Finally, the values if R, R square and Adjusted R square values of 0.960, 0.922 and 0.922 is each higher than the standard regression value of 0.4000 ; a computed $3515.033 \mathrm{~F}$ change and 2.82338 standard error, showed null hypothesis which says that transport system has no significant impact on FDIis hereby rejected, see Table 3.

Regression coefficient in table 4 showed .984 Beta standard coefficient higher than the standard Regression value of 0.4000 ; computed 6.880 Beta un-standardized coefficient and $t$ value of 95.828. Therefore the null hypothesis which states that Global business indicators have no significant impact on foreign direct investment is hereby rejected. Global business indicators have significant impact on foreign direct investment in Nigeria; the higher the global business indicators, the better the foreign direct investment. This finding is supported by previous research (Fahmi, 2012; Olival, 2012; Shahadan, Samidi \& Faizi, 2014; Singh, 2015; Hassan \& Basit, 2018).

Also table 4 showed .871 Beta standard coefficients higher than the standard regression value of 0.4000; computed 3.605 Beta un-standardized coefficients and t-value of 30.540. Therefore the null hypothesis which states that power supply has no significant impact on foreign direct investment, is hereby rejected. Power supply has inverse proportional relationship on foreign direct investment in Nigeria. This finding is in alignment with earlier studies (Oke, 2006; Okafor, 2008; Ekpo, 2009; Ologundudu, 2015; Olajunji, 2019)

Furthermore, table 4 showed .683 Beta standard coefficients higher than the standard Regression value of 0.4000 ; computed 3.418 Beta un-standardized coefficients and t-value of 16.142. Therefore the null hypothesis which states that security has no significant impact on foreign direct investment is hereby rejected. Security status of the studied country (Nigeria) has negative impact on ease of doing business in Nigeria, that is, the higher the insecurity, the lower the ease of doing business and the possibility of foreign direct investment. Earlier investigations such Godly and Wilfred (2012), Nwanegbo and Odigbo (2013), Ewetan and Urhie (2014), Udeh and Ihezie (2013), and Gylych, Kemal and Sotonye (2018) support this finding. Again, the Regression coefficient statistics in Table 4 shows .960 Beta standard coefficients higher than the standard Regression value of 0.4000 ; computed 8.185 Beta unstandardized coefficient and t-value of 59.288. Therefore the null hypothesis which states that transport system has no significant impact on foreign direct investment is hereby rejected. Transport system has negative impact on foreign direct investment in Nigeria that is the higher the poor transport system, the lower the foreign direct investment. Gulayani (2001), Djankov (2002), Agbigbe (2016) and World Economy Forum (2017) affirm this finding. 


\subsection{Managerial and Model Implications}

There should be vigorous power development in Nigeria such as uninterrupted power generation, distribution and electricity supply, as deficiency power supply negatively impact on foreign direct investment in Nigeria. The government should live up to its main responsibility of providing security for the country to stem the growing high level insecurity in the Nigeria as insecurity has negative impact on foreign direct investment. Nigeria should improve good friendly relationships with other countries through improved global business indicators which are directly proportional determinants on foreign direct investment. The poor transport system in Nigeria should be drastically reduced as this scare away potential investors and has negative impact on foreign direct investment

The study finally posits a model of dimensions of ease of doing business in Nigeria and perhaps other developing economies in order to attract foreign direct investment.

\subsection{Limitations and Direction for Further Research}

The major limitation of this study is the restriction of the research to respondents in Southeastern Nigeria which challenges the representativeness of the response across the country. Therefore, conclusions are cautionary. Future researches might be conducted in the six geo-political Zone of the country in order to enhance generalization of findings. Future research should be conducted in other Sub-Saharan African economies in order to test the applicability of the model in other low income countries of Sub-Saharan Africa

\subsection{Conclusion}

It can therefore be generally concluded that Nigeria still finds it difficult in terms of attracting FDI due to the complex nature of the business environment. The study specifically concluded that security, power supply and status of transport system all have significant but negative impact on foreign direct investment while global business indicators have significant but direct impact on ease of doing business to foreign direct investment in Nigeria. 
1. Starting Business

2. Registering Property

3. Getting Credit

4. Paying Taxes

5. Enforcing Contracts

6. Resolving Insolvency

7. Trading Across Borders

8. Construction Permits

9. Protecting Minority Share Holder

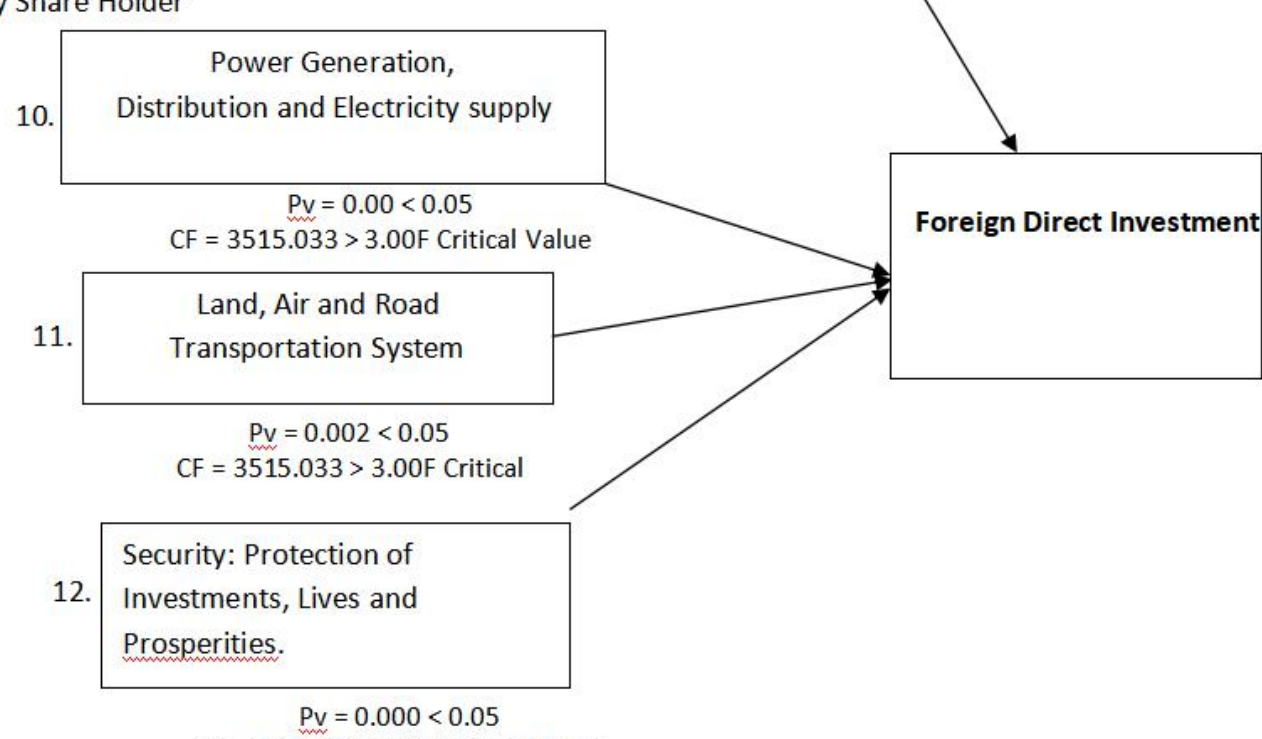

$\mathrm{CF}=260.568>3.00 \mathrm{~F}$ Critical Value

Figure 2: Dimensions of ease of doing business in Nigeria

\section{Acknowledgements:}

The authors acknowledge immensely the assistance of their colleagues in their respective universities who rendered review services which helped to improve the quality of the paper.

\section{References}

[1] Achumba, I. C., Ighomereho, I., \& Akpor-Robaro, M. O. (2013). Security challenges in Nigeria and the implications for business activities and sustainable economic development in Nigeria, Retrieved on August 21, 2020 from www.liste.org

[2] Agbigbe, W. A. (2016). The Impact of transportation infrastructure on Nigeria's economic development, Walden University Scholar Works, Walden Dissertation and Doctoral Studies Collection 
[3] Agrawal, G. (2015). Foreign direct investment and economic growth in BRICS Economies: A panel data analysis. Journal of Economics, Business and Management, $3(4)$.

[4] Akame, A J., Ekwelle, M. E., \& Njei, G. N. (2016). The impact of business climate on foreign direct investment in the CEMAC Region. Journal of Economics and Sustainable Development, 7 (22), 66-74

[5] Aremu. J. A. (1997). Foreign direct investment and performance. Paper delivered at a workshop on foreign investment policy and practice organized by the Nigerian Institute of Advanced Legal Studies, Lagos on 24 March.

[6] CBN (2013). Natural Resources Statistical Bulletin. Central Bank of Nigeria

[7] Daily Post, (2017), Nigerian government releases action plan for easing business. $\begin{array}{lllll}\text { Retrieved on } & \text { November } & 17, & 2020 \text { from }\end{array}$ www.google.com.ng/amp/dailypost.ng/2017/10/04/nigerian_releases_action_plan_ease_b usiness/amp

[8] Djankov, S. (2002). Regulation of entry. Quarterly Journal of Economics, CXVII (1)

[9] Durojaye, E. (2018). Ease of doing business in Nigeria: Recent changes in incorporation process. Advocaates Law Practice. Retrieved on September 10, 2020 from www.advocaat-law.com

[10] Ekpo, A. H. (2009). The global economic crisis and the crisis in Nigerian economy, presidential address to the $50^{\text {th }}$ Conference of the Nigerian Economic Society, AbujaNigeria

[11] Ewetam, O. \& Urhie, E. (2014). Insecurity and socio-economic development in Nigeria. Journal of Sustainable Development, 5 (1).

[12] Fahmi, M. R. (2012). Analyzing the relationship between tax holiday and foreign direct investment in Indonesia. Retrieved on July 18, 2020 from http://rcube.ac.jp/repo/repository/rcube/4740

[13] Friedrich Naumann Foundation (2017). 3 Reasons why ease of doing business in a country is important. Retrieved on June 6, 2020 from httds://asia.fnst.org/content/3reasons-why-ease-doing-business-country-important

[14] Godly, O. \& Wilfred, I .U (2012), National security and development in Nigeria. Africa Journal of Business Management, 6 (23).

[15] Gulyani, S. (2001). Effects of poor transportation on lean production and industrial clustering: Evidence from Indian auto industry, London: Palgrave, Macmillan. Retrieved on May 13, 2020 from https://lin.springer.com>chapter 
[16] Gylych, J; Kemal, O. \& Sotonye, O. B (2018). Impact of insecurity on investment in Nigeria. Jomeino International Journal, 2(3).

[17] Hassan, Z \& Basit, A. (2018). Ease of doing business and its impact on inward FDI. Retrieved on May 16, 2019.

[18] Igbinadolor, N.J (2019). Government agencies as barriers to ease of doing business in Nigeria, International conference on African trade development, United Kingdom.

[19] Jerome, A. \& Ogunkola, J. (2004). Foreign direct investment in Nigeria: magnitude, direction and prospects. Paper presented to the African Economic Research Consortium, Special Seminar Series. Nairobi.

[20] Mahuni, K \& Bonga, W. (2017). Nexus between doing business indicators and foreign direct investment for Zimbabwe: A Time Series Analysis. Journal of Economics and Finance, 2(2), 1-8

[21] MogesEbero, E. \& Begum, M. (2016). The desirability of doing business and flow of foreign direct investment nexus: The case of Ethiopia. International Research Journal of Engineering and Technology, 3(5), 2049-2057

[22] Muntah, S., Khan, M., Haider, N., \& Ahmad, A. (2015). Impact of foreign direct investment on economic growth of Pakistan. American Research Journal of Business and Management, 1 (1)

[23] Nwanegbo, C. J. \& Odigo, S. (2013). Security and national development in Nigeria: The threat of Boko Haram. International Journal of Humanities and Social Science, 4.

[24] Nwankwo, O.G, Ademola, O. \& Kehinde, O. (2013). Effects of globalization on foreign direct investment In Nigeria. Lorem Journal of Business and Economics (LJBE) 1(1), 1117.

[25] Obinna, O. E. (1983). Diversification of Nigeria's external finances through strategic foreign direct investment. Nigerian Economic Society Annual Conference Proceedings, Jos, 13-16th May

[26] Okafor, E. O. (2008). Development crisis of the power supply and implications for industrial sector in Nigeria. Kamla-Raj Journal, 6

[27] Oke, O. A. (2006). Impact of Energy on the Manufacturing Sector in Nigeria, Retrieved on September 6, 2020 from www.fypower.org/pdf/mfg

[28] Okri, B (2020). Ease of Doing Business in Nigeria, Presented at $10^{\text {th }}$ International Conference of Global Economic Policy Initiative at Ikeja Airport Hotel, Lagos- Nigeria 
[29] Olagunju, O.O. \& Ikeolumba, J.O. (2019). The evaluation of the national policy on Ease of doing business in Nigeria. European Scientific Journal, 15, Doi:10.19044/esj2019.v15n8p216.

[30] Ologundudu, M. M. (2015). The impact of electricity supply on industrial and economic performance in Nigeria. International Global Journal of Management and Research, 2 (4).

[31] Olival, A. (2012). The influence of doing business institutional variables in foreign direct investment, Doctoral Dissertation, Oxford University

[32] Onu, A.J.C. (2012). Impact of foreign direct investment on economic growth in Nigeria, Interdisciplinary Journal of Contemporary Research in Business, 4(5), 64-75.

[33] Redefining the Ease of Doing Business, (2016). Detail Commercial Solicitors, Lagos, Nigeria. Retrieved on June 23, 2020 from https://pdfs.semanticscholar.org.

[34] Shahadan, F., Sarmidi, T., \& Faizi, F. (2014). Relationship between doing business indexes and FDI net inflows: Empirical evidence from six Asian countries, In Prosiding Persidangan Kebangsaan Ekonomi Malaysia Ke-9

[35] Singh, G. (2015). Relationship between doing business Index and foreign direct investment, In International conference on ease of doing business: Contemporary issues, challenges and future scope, Ahmedabed

[36] Solomon, H.C \& Eka, O.O. (2013). Impact of foreign direct investment on telecommunication sector on Nigerian economy. International Journal of Modern Social Sciences, 2(3), 195-215.

[37] Udeh, S. C. \& Ihezie, U. R. (2013). Insecurity and national economic development: Implications for Nigeria's 2020. International Journal of Development and Management Review, 8

[38] United Nations Conference on Trade and Development (UNCTAD) (2019). Ease of doing business in Nigeria, World investment report special economic zone, Washington

[39] Uwubanmwen, A. E. \& Ogiemudia, O. A. (2016). Foreign direct investment and economic growth: Evidence from Nigeria. International Journal of Business and Social Sciences, 7(3).

[40] World Bank, (2020). Doing business report, KPMG's online Nigeria

[41] World Bank, (2016). World debt analysis and tables: External finance for developing countries, .3 (Analysis and Summary Tables). Washington, D. C.

[42] World Bank Group, (2011) Doing Business, Measuring Business Regulation. 
[43] World Business Group, (2018). Doing business in Nigeria, Sub-national doing business, comparing business regulations for domestic firms in 36 states and FCT Abuja with 189 economies

[44] World Economy Forum (2017). The global competitiveness report. Retrieved on October 16 , 2020 fromwww.weforum.org/docs/GCR2016/2017/05FullReport/TheGlobalCompetivenessRe port2016-2017_FINAL.pdf

[45] Yusuf, M (2019). Exclusive Nigeria indicators for ease of doing business, business.ng, Lagos Chamber of Commerce and Industry (LCCI), Business Daily Online 